\title{
Evaluasi Keterampilan Peternak dalam Menerapkan Aspek Teknis Pemeliharaan Sapi Potong di Kecamatan Koto Besar Kabupaten Dharmasraya
}

\author{
Evaluation of Farmers' Skills in Applying Technical Aspects of Keeping Cattle in Koto Besar \\ District, Dharmasraya Regency
}

\section{Yendraliza, T. Adelina dan Amdes}

Faculty of Agriculture and Animal Science, Universitas Islam Negeri Sultan Syarif Kasim Riau Jl. H.R. Soebrantas No. 155 KM.15. Simpang Baru, Panam, Pekanbaru 28293

Corresponding e-mail: yendraliza@uin-suska.ac.id

\begin{abstract}
The beef cattle breeding system in Koto Besar Subdistrict in Dharmasraya Regency is still a type of small-scale farm with the traditional breeding system. The purpose of this study was to find out the implementation of technical aspects in accordance with Permentan NO. 46 / Permentan / PK.210 / 8/2015, structure population and natural increase. This research was conducted in August to September 2019 at the location of smallholder farms in Koto Besar Subdistrict, Dharmasraya Regency. The method used in this study is a survey method obtained from 38 breeders with 182 Bali cattle. The variables in this research are the respondent profile, breeding aspects, housing, feed aspects and structure population on the maintenance of cattle. The results of this study indicate that breeders are in productive age with education (SD-PT) and good experience (8 years). Farmers $(60.53 \%)$ have never received training in animal husbandry technology. The technical aspects of maintenance are good for the aspects of breeding $(91.45 \%)$, and the housing aspects $(90.06 \%)$, while the feeding aspect $(50.00 \%)$, this category is lacking. The population structure is dominated by cows with natural increase (NI) $(21.47 \%)$. The conclusion in this study the application of technical aspects which include aspects of breeding and housing are good, except the aspect of feed. Population structure of 1: 4 with a Natural increase of $21.47 \%$.
\end{abstract}

Key words: Breeding aspects, feed aspects, housing aspects

\begin{abstract}
ABSTRAK
Sistem pembibitan sapi potong yang ada di Kecamatan Koto Besar di Kabupaten Dharmasraya masih merupakan jenis peternakan skala kecil dengan sistem pemeliharaan traditional. Tujuan dari penelitian ini adalah untuk mengetahui penerapan aspek teknis sesuai dengan Permentan NO. 46 / Permentan / PK.210 / 8/2015, struktur populasi dan peningkatan alami. Penelitian ini dilakukan pada bulan Agustus hingga September 2019 di lokasi pertanian rakyat di Kecamatan Koto Besar, Kabupaten Dharmasraya. Metode yang digunakan dalam penelitian ini adalah metode survei yang diperoleh dari 38 peternak dengan 182 sapi Bali. Variabel dalam penelitian ini adalah profil responden, aspek pemuliaan, perumahan, aspek pakan dan struktur populasi pada pemeliharaan ternak. Hasil penelitian ini menunjukkan bahwa peternak berada dalam usia produktif dengan pendidikan (SDPT) dan pengalaman yang baik ( 8 tahun). $60,53 \%$ peternak tidak pernah menerima pelatihan teknologi peternakan. Aspek teknis pemeliharaan baik untuk aspek pemuliaan $91,45 \%$, dan aspek perumahan 90,06\%, sedangkan aspek pemberian makan 50,00\% kategori kurang. Struktur populasi didominasi oleh sapi dengan peningkatan alami (NI) $21,47 \%$. Kesimpulan dalam penelitian ini penerapan aspek teknis yang meliputi aspek pemuliaan, perumahan yang baik kecuali aspek pakan. Struktur populasi 1: 4 dengan peningkatan alami $21,47 \%$.
\end{abstract}

Kata kunci: aspek perkawinan, aspek pakan, aspek perkandangan

\section{PENDAHULUAN}

Kabupaten Dhamasraya merupakan wilayah strategi yang terletak antara Provinsi Riau dan Provinsi Jambi sehingga mudah dalam pemasaran ternak. Keunggulan lainnya, Kabupaten Dhamasraya memiliki sarana dan prasarana peternakan seperti petugas IB, dinas keswan, distributor obat-obatan dan pakan. Kabupaten Dharmasraya merupakan suatu wilayah yang memiliki potensi dalam pemeliharaan sapi karena daerah tersebut memiliki sumber daya manusia dan sumber daya alam. Total populasi sapi potong di Kabupaten Dharmasraya 12.666 ekor dan sebagian besar adalah sapi Bali (Dinas Pertanian dan Peternakan Kabupaten Dharmasraya, 2018; (Ediset dan Heriyanto, 2012). Salah satu kecamatan yang memiliki populasi sapi terbesar adalah Kecamatan Koto Baru 5.299 ekor sapi Potong. 
Peternakan berkelanjutan ditentukan oleh peternak, ternak dan fasilitas pendukungnya. Aspek pengembangan yang dapat dilakukan oleh peternak dalam meningkatkan populasi tertuang dalam Permentan No. 46/Permentan/PK.210/8/2015. Keberhasilan peternak dalam mengelola peternakan sangat penting untuk diperhitungkan. aspek penting yang harus di perhatikan dalam manajemen pemeliharaan sapi potong yaitu aspek feeding (pemberian pakan), breeding (pembibitan) dan manajemen. Peternak yang mampu mengelola penggunaan sumberdaya (input) yang ada untuk mencapai output maksimum (Costa et al., 2013). Peningkatan jumlah populasi merupakan salah satu indikator, peternak memiliki manajerial yang baik dalam memelihara ternak. Pertambahan alami ternak dapat dilihat dari struktur populasi (Kusuma et al, 2017). Beberapa penelitian yang telah dilakukan di Kecamatan Koto Besar adalah analisa potensi wilayah (Ediset dan Heriyanto, 2012). Potensi kelompok ternak sapi, struktur populasi dan pertambahan alami (NI) ternak belum di teliti.

Penelitian ini dilakukan dengan tujuan untuk mengetahui pelaksanaan penerapan aspek teknis pemeliharaan oleh peternak, struktur populasi dan natural increase sapi potong oleh kelompok ternak di Kecamatan Koto Besar Kabupaten Dharmasraya. Data yang dihasilkan diharapkan dapat memberikan informasi dan menjadi bahan pertimbangan dalam perbaikan tatalaksana pemeliharaan sapi potong di daerah Dhamasraya.

\section{MATERI DAN METODE}

Penelitian ini difokuskan pada peternak yang tergabung dalam kelompok tani di Kecamatan Koto Besar Kabupaten Dharmasraya. Penelitian dilaksanakan pada bulan Agustus sampai dengan bulan September 2019.

Materi penelitian ini terdiri dari 38 peternak sapi yang telah memelihara ternak selama 3 tahun dan tergabung dalam kelompok tani. Kelompok tani yang terpilih adalah kelompok Tani Usaha Murni, Kelompok Tani Usaha Bersama, Kelompok Tani Mutiara, Kelompok Tani Sungai Bilangan, Kelompok Tani Rumbai Sepakat.

\section{Parameter yang Diukur}

1. Profil Responden
Yaitu jenis kelamin peternak, umur, tingkat pendidikan, pengalaman beternak, dan tingkat pendapatan dari peternak tersebut.

\section{Aspek Pemeliharaan terdiri dari}

a. Aspek pembibitan

Yaitu bangsa sapi yang dipelihara dan cara perkawinan. Berdasarkan Permentan No.46/Permentan/PK.210/ 8/2015, perkawinan pada Pola intensif, semi intensif, dan ekstensif dapat dilakukan dengan cara kawin alam dan/atau Inseminasi Buatan (IB).

\section{b. Aspek Kandang}

Kandang yang baik akan meningkatkan produktivitas usaha peternakan. Berdasarkan Permentan No.46/Permentan/PK.210/ 8/2015.

\section{c. Aspek Pakan}

Yaitu cara pemberian hijauan dan frekuensi pemberian hijauan, jumlah pemberian hijauan, cara pemberian konsentrat, jumlah pemberian konsentrat dan frekuensi pemberian konsentrat. Berdasarkan Permentan No.46/Permentan/PK.210/ 8/2015.

\section{Struktur Populasi}

Struktur populasi di lihat dari jumlah ternak per tingkatan umur yang meliputi angka kelahiran dan angka kematian serta pertambahan alami (natural increase).

Natural increase dihitung dengan cara mengurangi persentase kelahiran dengan persentase kematian dalam satu kelompok tani pertahun.

Nilai/skor yang diperoleh dibandingkan dengan kategori yang ditetapkan Permentan No.46/Permentan/PK.210/ 8/2015 yaitu : Kategori baik, jika persentase skor yang diperoleh 81-100\%; Kategori sedang, jika persentase skor yang diperoleh $60-80 \%$; Kategori kurang, jika persentase skor yang diperoleh kecil dari $60 \%$.

\section{Analisis Data}

Karakteristik peternak dianalisis secara deskriptif dan ditampilkan dengan frekuensi. Ketrampilan teknis peternak dianalisis dengan membandingkan nilai hasil pengamatan dengan standar Permentan 2015.

\section{HASIL DAN PEMBAHASAN}

\section{Karakteristik Responden}

Rataan responden peternak sapi adalah laki-laki, berusia 30 tahun $->55$ tahun dengan pendidikan tertinggi sekolah menengah atas. 
Mata pencarian utama responden adalah bertani. Total lahan yang dimiliki responden adalah 1.2 Ha, dengan total kepemilikan ternak adalah 3 ekor sapi/petani (Tabel 1). Permana et al, (2014) menyatakan bahwa skala kepemilikan ternak memberikan pengaruh yang positif terhadap pendapatan peternak. Rata-rata usia peternak berada dalam usia produktif dan memiliki pengalaman beternak yang baik (Cahyawati, 2015).

\section{Aspek Teknis Pemeliharaan}

Aspek Pembibitan
Rataan responden telah melaksanakan aspek pembibitan dengan total score 91.45\% (Tabel 2) tergolong baik. Nilai aspek pembibitan yang baik ini disebabkan oleh sebagian besar peternak udah melaksanakan seleksi bibit dan ternak pengganti, namun hanya sedikit peternak yang melakukan recording dan judging. Hal ini disebabkan karena peternak tergabung dalam kelompok tani. Sehingga bibit ternak telah disediakan oleh pemerintah. Lemahnya aspek ini terlihat dari pertumbuhan populasi di Kecamatan Koto Besar yang rendah, bahwa hanya 14 ekor jumlah sapi yang lahir dari 112 induk sapi yang ada.

Tabel 1. Karakteristik jenis kelamin peternak sapi potong di Kecamatan Koto Besar

\begin{tabular}{|c|c|c|}
\hline Karakteristik & Jumlah & Persentase $(\%)$ \\
\hline \multicolumn{3}{|c|}{ Jenis Kelamin Peternak } \\
\hline Laki-laki & 38 & 100,00 \\
\hline Perempuan & 0 & 0,00 \\
\hline \multicolumn{3}{|l|}{ Umur Peternak } \\
\hline$<35$ Tahun & 8 & 21,05 \\
\hline 35-44 Tahun & 9 & 23,68 \\
\hline 45-54 Tahun & 9 & 23,68 \\
\hline$>55$ Tahun & 12 & 31,58 \\
\hline \multicolumn{3}{|c|}{ Pendidikan Formal Peternak } \\
\hline Tidak Sekolah & 0 & 0,00 \\
\hline SD & 19 & 50,00 \\
\hline SMP & 4 & 10,53 \\
\hline SMA & 13 & 34,21 \\
\hline Perguruan Tinggi & 2 & 5,26 \\
\hline \multicolumn{3}{|c|}{ Pengalaman Beternak } \\
\hline$<1$ Tahun & 4 & 10,53 \\
\hline 1-8 Tahun & 19 & 50,00 \\
\hline 9-20 Tahun & 10 & 26,32 \\
\hline$>20$ Tahun & 5 & 13,16 \\
\hline \multicolumn{3}{|l|}{ Pekerjaan Utama } \\
\hline Petani/Peternak & 37 & 97,37 \\
\hline Wiraswasta & 1 & 2,63 \\
\hline Pedagang & 0 & 0,00 \\
\hline PNS & 0 & 0,00 \\
\hline Tukang & 0 & 0,00 \\
\hline \multicolumn{3}{|l|}{ Kepemilikan } \\
\hline Pemilik & 33 & 86,84 \\
\hline Pekerja & 5 & 13,16 \\
\hline Dll & 0 & 0,00 \\
\hline \multicolumn{3}{|c|}{ Penyuluhan / Pelatihan Peternakan } \\
\hline Pernah & 15 & 39,47 \\
\hline Tidak Pernah & 23 & 60,53 \\
\hline Jumlah & 38 & 100,00 \\
\hline
\end{tabular}


Tabel 2. Penilaian aspek pembibitan pada peternak sapi Bali di Kecamatan Koto Besar

\begin{tabular}{clccc}
\hline \multirow{2}{*}{ No } & \multirow{2}{*}{ Pengamatan } & \multicolumn{2}{c}{ Melaksanakan } & Kategori penerapan \\
\cline { 3 - 5 } & Sumlah & $\%$ & \\
\hline 1 & Seleksi Bibit & 38 & 100,00 & baik \\
2 & Recording & 38 & 100,00 & baik \\
3 & Replacement Stock & 27 & 71,05 & sedang \\
4 & Judging & 36 & 94,74 & baik \\
5 & Metode Perkawinan & & & \\
& a. Alami & 0 & 0,00 & 0 \\
& b. IB & 38 & 100,00 & Sangat baik \\
\hline & Rataan & & $91,45 \%$ & baik \\
\hline
\end{tabular}

Costa et al. (2013) menyatakan bahwa jumlah sapi memiliki hubungan yang positif dengan aspek pemeliharaan. Kelemahan replacement stock ini juga disebabkan kurangnya pengetahuan peternak tentang manfaat replacement stock. Hal ini terlihat dari rendahnya persentase penyuluhan yang diikuti oleh peternak. Widjastuti et al. (2017) menyatakan bahwa pemahaman peternak berbanding lurus dengan penyuluhan yang dilakukan. Persentase peternak yang melaksanakan teknis pembibitan dalam penelitian ini $(91,45 \%)$ lebih tinggi dari peternak di Desa Bagan Sinembah (4,17\%) (Saherman et al., 2007) dan peternak di Gayo Lues (41,71\%) (Sari et al., 2015). Perbedaan kemampuan pelaksanaan pembibitan pada peternak ini disebabkan oleh pemahaman, tujuan beternak, dan pendidikan peternak yang berbeda (Fauziyah et al., 2017).

\section{Aspek Kandang}

Rataan nilai aspek perkandangan yang diperoleh peternak sapi di Kecamatan Koto Besar dalam penelitian ini adalah baik (Tabel 3). Kandang yang digunakan sudah memenuhi standar dilihat dari tata letak, perlengkapan dan drainase kecuali untuk konstruksi dan luas kandang belum mendapatkan nilai yang sempurna. Luas kandang individu disesuaikan dengan ukuran tubuh sapi yaitu 2,5 x 1,5 meter (Marsuma et al., 2016).

Tabel 3. Penilaian aspek kandang pada peternak sapi Bali di Kecamatan Koto Besar

\begin{tabular}{llccc}
\hline \multirow{2}{*}{ No Pengamatan } & \multicolumn{3}{c}{ Pelaksanaan } & \\
\cline { 3 - 5 } & & Jumlah & $\%$ & $\begin{array}{c}\text { Kategori } \\
\text { penerapan }\end{array}$ \\
\hline 1 & Penggunaan Kandang & 38 & 100,00 & baik \\
2 & Jarak Kandang & 38 & 100,00 & baik \\
3 & Sinar Matahari Pagi & 38 & 100,00 & baik \\
4 & Perlengkapan Kandang & 38 & 100,00 & baik \\
5 & Drainase & 38 & 100,00 & baik \\
6 & Konstruksi Kandang & & & \\
& Baik & 38 & 100,00 & baik \\
& Sedang & 0 & 0,00 & \\
& Kurang & 0 & 0,00 & \\
7 & Kebersihan Kandang & & & \\
& Baik & 31 & 81,58 & baik \\
& Sedang & 7 & 18,42 & \\
\hline \multirow{2}{*}{8} & Kurang & 0 & 0,00 & \\
& Bahan Kandang & & & \\
& Bambu & 0 & 0,00 & \\
& Kayu & 11 & 28,95 & baik \\
9 & Semen & 27 & 71,05 & baik \\
& Luas Kandang & & & \\
\hline & 5-10 m persegi & 16 & 42,11 & baik \\
\hline
\end{tabular}


Kandang merupakan social control ternak dari perubahan cuaca dan iklim yang ekstrim, mencegah dan melindungi ternak dari penyakit, menjaga keamanan ternak dari pencurian, memudahkan pengelolaan ternak, serta meningkatkan efisiensi penggunaan tenaga kerja (Jensen dan Larsen, 2014).

Kandang yang digunakan berbentuk koloni, dengan bahan yang mudah didapatkan disekitar desa sehingga daya tahan kandang agak rendah. Hal ini dilakukan oleh peternak untuk menekan biaya membuat kandang. Maryam et al. (2016) menyatakan bahwa selain bibit dan pakan maka biaya kandang merupakan hal yang penting dalam peternakan.

Aspek perkandangan peternak sapi potong di Kecamatan Koto Besar (90,06\%) lebih tinggi dibandingkan dengan Peternak di Desa Bagan Sinembah $(55,66 \%)$ (Saherman et al., 2007) dan petenak di daerah Gayo Lues (74,78\%) (Sari et al., 2015). Hal ini disebabkan adanya perbedaan pemahaman peternak dalam aspek perkandangan. Selain itu tujuan beternak juga menentukan aspek perkandangan yang dilakukan (Permana et al., 2014).

\section{Aspek Pakan}

Rerata peternak sapi potong di Kecamatan Koto Baru memberikan pakan hijauan dengan kombinasi rumput lapang dan rumput unggul (Tabel 4). Hal ini disebabkan pakan hijauan tersedia tetapi jumlah yang diberikan belum mencukupi. Sehinggal nilai ketercukupan pakan amat rendah. Pakan konsentrat hanya diberikan oleh beberapa orang. Pemahaman dan pengetahuan peternak sangat menentukan pemberian pakan pada ternak (Simamora et al., 2015).

Aspek pakan peternak sapi potong di Kecamatan Koto Besar dalam penelitian ini $(50,00 \%)$ lebih tinggi dibandingkan peternak di Desa Bagan Sinembah 3,34\% (Saherman et al., 2007) dan peternak di daerah Gayo Lues aspek pakan mencapai persentase 18\% (Sari et al., 2015). Hal ini disebabkan masih banyak peternak yang belum mengetahui jumlah dan kualitas hijauan yang harus diberikan. Kurangnya penyuluhan dan rendahnya pendidikan masyarakat menyebabkan pemahaman peternak dalam menyusun ransum, jumlah dan batasan serta pentingnya pemberian pakan, kurang (Huzzey et al., 2012).

\section{Struktur Populasi dan Natural Increase}

Total populasi ternak sapi yang di pelihara kelompok tani adalah 182 ekor setara dengan 140 ST. Perbandingan jantan dan betina adalah 1: 4 (Tabel 5). Persentase kelahiran ternak sapi adalah $41.66 \%$ dengan pertambahan alami (natural increase (NI) 21.47\% (Tabel 6). artinya pertambahan populasi ternak sapi di kelompok ternak pertahun adalah $21.47 \%$. (Kusuma et al., 2017) menyatakan bahwa penentuan kategori NI rendah, sedang dan tinggi ditentukan dengan membagi hasil persentase populasi induk terhadap populasi rata-rata. Kategori nilai NI sapi potong dalam kelompok tani di Kecamatan Koto Besar, Dhamasraya adalah sedang (tinggi : 35.18-52.76; sedang: 17.59 - 35.17; rendah: 0-17.58).

Tabel 4. Penilaian aspek pakan pada peternak sapi Bali di Kecamatan Koto Besar

\begin{tabular}{|c|c|c|c|c|c|c|}
\hline \multirow[t]{2}{*}{ No } & \multirow[t]{2}{*}{ Pengamatan } & \multicolumn{2}{|c|}{ Melaksanakan } & \multicolumn{2}{|c|}{$\begin{array}{c}\text { Tidak } \\
\text { Melaksanakan } \\
\end{array}$} & \multirow{2}{*}{$\begin{array}{r}\text { Kategori } \\
\text { Penerapar } \\
\text { Jumlah } \\
\end{array}$} \\
\hline & & Jumlah & $\%$ & Jumlah & $\%$ & \\
\hline 1 & Pakan di kandang & 38 & 100,00 & 0 & 0,00 & baik \\
\hline 2 & Batas Pemberian & 9 & 23,68 & 29 & 76,32 & kurang \\
\hline 3 & Rumput Unggul & 38 & 100,00 & 0 & 0,00 & baik \\
\hline 4 & Konsentrat & 22 & 57,89 & 16 & 42,11 & cukup \\
\hline 5 & Ransum Susun & 7 & 18,42 & 31 & 81,58 & kurang \\
\hline 6 & Limbah Sebagai Pakan & 12 & 31,58 & 26 & 68,42 & kurang \\
\hline 7 & Pengetahuan Teknologi & 16 & 42,11 & 22 & 57,89 & kurang \\
\hline \multirow[t]{2}{*}{8} & Penerapan Teknologi & 10 & 26,32 & 28 & 73,68 & kurang \\
\hline & Rataan & \multicolumn{3}{|c|}{$50,00 \%$} & Kurang & \\
\hline
\end{tabular}


Tabel 5. Struktur populasi ternak sapi kelompok tani di Kecamatan Koto Besar, Dhamasraya

\begin{tabular}{llccc}
\hline Umur & Status Fisiologis & $\begin{array}{c}\text { Jumlah } \\
\text { (ekor) }\end{array}$ & $\begin{array}{c}\text { Persentase } \\
(\%)\end{array}$ & $\begin{array}{c}\text { Satuan ternak } \\
(\text { ST) }\end{array}$ \\
\hline Dewasa & Pejantan & 22 & 12.08 & 22 \\
\multirow{3}{*}{ Muda } & Induk & 96 & 52.74 & 96 \\
& Jantan Muda & 7 & 3.8 & 3.5 \\
\multirow{2}{*}{ Pedet } & Dara & 17 & 9.3 & 8.5 \\
& Jantan & 10 & 5.49 & 2.5 \\
Total & Betina & 30 & 16.48 & 7.5 \\
& Jantan & 39 & 21.42 & \\
\hline Total & Betina & 143 & 78.57 & 140 \\
\hline
\end{tabular}

Tabel 6. Natural increase sapi potong kelompok tani di Kecamatan Koto Besar, Dhamasraya

\begin{tabular}{ll}
\hline Peubah & Jumlah \\
\hline Populasi (ekor) & 182 \\
Populasi Induk (ekor) & 96 \\
Populasi induk terhadap populasi rerata (\%) & 52.74 \\
Kelahiran & \\
a. Jantan (ekor) & 10 \\
$\quad$ Terhadap induk (\%) & 10.41 \\
Terhadap populasi rerata (\%) & 5.49 \\
b. Betina (ekor) & 30 \\
Terhadap induk (\%) & 31.25 \\
Terhadap populasi rerata (\%) & 16.48 \\
Tingkat Kelahiran & 40 \\
$\quad$ a. Terhadap induk (\%) & 41.66 \\
$\quad$ b. Terhadap populasi rerata (\%) & 21.97 \\
Kematian terhadap populasi (ekor) & 1 \\
Kematian terhadap populasi (\%) & 0.5 \\
Natural Increase (\%) & 21.47 \\
\hline
\end{tabular}

Nilai NI sapi potong pada kelompok tani di Kecamatan Koto Besar ini lebih tinggi dari sapi potong di Papua (Samberi et al., 2010) dan sapi potong di Kecamatan Bayang; (Afriani et al., 2019) $(21.47 \%$ VS $18.18 \% ; 17.64 \%$ ) dan lebih rendah dari sapi potong di Pesisir (Putra et al., 2015), (21.47\% VS 29.96\%).

Rendahnya nilai NI pada kelompok tani di Kecamatan Koto Besar, Dhamasraya ini menandakan bahwa penegelolaan sapi belum dilakukan dengan maksimal. Hal ini terlihat bahwa dari populasi induk yang ada, hanya $40 \%$ yang melahirkan. Untuk itu perlu ada upaya mempertahankan betina produktif dan meningkatkan jumlah betina produktif. Sumadi et al. (2017) menyatakan bahwa nilai NI yang baik perlu dipertahankan dengan melestarikan betinabetina yang produktif dan meniadakan kematian pedet.

\section{KESIMPULAN}

Karakteristik peternak $(100 \%)$ berjenis kelamin laki-laki, dengan usia diatas 35 tahun. Tingkat pendidikan $50 \%$ tamatan SD, rata-rata pengalaman beternak 8 tahun, $86,84 \%$ responden sebagai pemilik ternak dan lahan peternakannya, $60,53 \%$ responden belum pernah memperoleh penyuluhan dan pelatihan teknologi peternakan. Aspek teknis pemeliharaan kategori baik pada aspek pembibitan 91,45\%, dan aspek perkandangan $90,06 \%$, sedangkan aspek pemberian pakan $50,00 \%$ kategori kurang. Struktur populasi didominasi betina dengan 21,47 $\%$ angka pertambahan alami (NI).

\section{DAFTAR PUSTAKA}

Afriani, T., M.P. Agusta, Yurnalis, F. Arlina dan D.E. Putra. 2019. Estimasi Dinamika Populasi dan Pembibitan Sapi Potong di Kecamatan Bayang Kabupaten Pesisir 
Selatan. Jurnal Peternakan Indonesia 21(2): $\quad 130-142 . \quad$ doi: 10.25077/jpi.21.2.130-142.2019.

Cahyawati, A. E. 2015. Analisis Efisiensi Teknis, Ketrampilan Teknis Beternak dan Pendapatan pada Usaha Peternakan Sapi Perah Rakyat di Kecamatan Lembang. Thesis, IPB Bogor.

Costa, J.H.C., M. J. Hötzel, C. Longo, L. F. Balcão. 2013. A survey of management practices that influence production and welfare of dairy cattle on family farms in southern Brazil. Journal of Dairy Science 96(1): 307-317. doi: 10.3168/jds.20125906.

Ediset and E. Heriyanto. 2012. Analisis Potensi Wilayah Dharmasraya untuk Pengembangan Sapi Potong dan Kaitannya dengan Pemberdayaan Ekonomi Masyarakat. Jurnal Peternakan Indonesia 14(3): 425-432. doi: 10.1017/CBO9781107415324.004.

Fauziyah, D., R. Nurmalina and B. Burhanuddin. 2017. Pengaruh Karakteristik Peternak Melalui Kompetensi Peternak terhadap Kinerja Usaha Ternak Sapi Potong di Kabupaten Bandung. Jurnal Agribisnis Indonesia 3(2): 83-96. doi: 10.29244/jai.2015.3.2.83-96.

Huzzey, J., R. Grant and T. Overton. 2012. Short communication: Relationship between competitive success during displacements at an overstocked feed bunk and measures of physiology and behavior in Holstein dairy cattle. Journal of Dairy Science 95(8): 4434-4441. doi: 10.3168/jds.2011-5038.

Jensen, M. and L. Larsen. 2014. Effects of level of social contact on dairy calf behavior and health. Journal of Dairy Science 97(8): $\quad 5035-5044 . \quad$ doi: 10.3168/jds.2013-7311.

Kusuma, S. B., N. Ngadiyono dan S. Sumadi. 2017. Estimasi Dinamika Populasi dan Penampilan Reproduksi Sapi Peranakan Ongole di Kabupaten Kebumen Provinsi Jawa Tengah. Buletin Peternakan 41(3):
230-242.

doi: 10.21059/buletinpeternak.v41i3.13618.

Marsuma, K., S. Kuswaryan dan D. Budinuryanto. 2016. Pengaruh Penerapan Asas Kesejahteraan Ternak terhadap Nilai Penjualan Domba. Jurnal Unpad, $1-12$.

Maryam, M. B. Paly dan Astati. 2016. Analisis faktor-faktor yang mempengaruhi penentu pendapatan usaha peternakan sapi potong (studi kasus Desa Otting Kabupaten Bone). Jurnal Ilmu dan Industri Peternakan 3 (1): 79-101.

Permana, A., A. H. Daulay dan I. Sembiring. 2014. Analisis Profil Peternak Terhadap Pendapatan Peternak Sapi Potong di Kecamatan Pancur Batu Kabupaten Deli Serdang. Jurnal Peternakan Integratif 2(1): $1-12$.

Putra, D. E., Sumadi dan T. Hartatik. 2015. Estimasi Output Sapi Potong di Kabupaten Pesisir Selatan Provinsi Sumatera Barat. Jurnal Peternakan Indonesia 17(2): 105-115.

Saherman, I., D. Febrina dan D. Hidayati. 2007. Penerapan Aspek Teknis Pemeliharaan Sapi Potong di Desa Bagan Sinembah Kecamatan Bagan Sinembah Kabupaten Rokan Hilir. Jurnal Peternakan 4 (2): 57 64. doi: 10.24014/jupet.v4i2.272.

Samberi, K., Y. N. Ngadiyono dan Sumadi. 2010. Estimasi dinamika populasi dan produktivitas sapi Bali di Kabupaten Kepulauan Yapen, Propinsi Papua. Buletin Peternakan 34 (3): 169-177.

Sari, E. M., M. Abdullah dan S. Sulaiman. 2015. Kajian Aspek Teknis Pemeliharaan Kerbau Lokal Di Kabupaten Gayo Lues. Jurnal Agripet 15(1): 57. doi: 10.17969/agripet.v15i1.2301.

Simamora, T., A. M. Fuah, dan A. Atabany. 2015. Evaluasi Aspek Teknis Peternakan Sapi Perah Rakyat di Kabupaten Karo Sumatera Utara. Jurnal Ilmu Produksi dan Teknologi Hasil Peternakan 3(1): 52-58. doi: 10.29244/jipthp.3.1.52-58. 
Sumadi, A. Fathoni, S. B. Kusuma, D. N. H. Hariyono. 2017. The Estimation of Natural Increase, Population Dinamics and Output of Beff Cattle in Klaten Central of Java. in The 7th International Seminar on Tropical Animal Production, Contribution of Livestock Production on Food Sovereignty in Tropical Countries September 12-14, Yogyakarta, Indonesia, pp. $760-764$.
Widjastuti, T. W. Tanwiriah, Abun, D. Garrnida. 2017. Peningkatan Keterampilan Budi Daya Ternak Ayam Melalui Penerapan Teknologi Peternakan di Desa Gagasari Dan Kalimaro Kabupaten Cirebon. Ilmu Pengabdian Kepada Masyarakat, 1(4): 266-270. 